\title{
Social Problems
}

\author{
Günter Albrecht
}

\begin{abstract}
A review of the German-language literature on social problems is confronted with the major difficulty that social problems are analyzed by many special sociologies (e.g., the sociology of deviant behavior and social control) without any explicit reference to the category of "social problems." The present review will deal with this by concentrating on those publications that use the concept of "social problems" as developed in the controversies between structural functionalists (e.g., Robert Merton) on the one hand and symbolic interactionists (e.g., Herbert Blumer, Malcom Spector, John L. Kitsuse) and radical constructionists on the other. In German-language sociology, the latter approaches gained prevalence and have marginalized the "objectivist" position. Recent publications have been dedicated to analyses of "doing social problems." It is, however, not always obvious how these analyses differ from the traditional labeling approach. Just as in the international literature, its German-language counterparts offer only few examples of internationally comparative studies of social problems and their constitution, even though such analyses would allow us to identify which conditions are relevant to the career of social problems.
\end{abstract}

Keywords: Theory of social problems, structural functionalism, symbolic interactionism, constructivism, social movements, career of social problems

\section{Introduction}

Reviewing the literature for trends in the sociology of social problems in Germanspeaking countries faces major difficulties as the concept of "social problems" is ubiquitous in everyday language; the term is applied to all kinds of things that somehow seem to be "problematic." To minimize these difficulties, the following article begins by outlining what a sociology of social problems could be. For this purpose, let us recall an earlier debate of what such a sociology might be-one that was conducted from exactly this perspective in American sociology between the "classical” structural-functionalist position of Robert K. Merton and the advocates of symbolic interactionism. This debate, in which symbolic interactionists massively attacked Merton's position, not only triggered a complete reorientation of the sociology of social problems at the time but can also serve to demonstrate the significance that the process involved in constituting social problems has gained (2). After eluci-

Note: Translation from German by Stephan Elkins (SocioTrans-Social Science Translation \& Editing).

Dedication: For my lovely wife, Irmgard, for her 75th birthday and to express my gratitude for our being together for 60 years through times both good and not so good.

Ә OpenAccess. (c) 2021 Günter Albrecht, published by De Gruyter. (c))BY-NC-ND This work is licensed under the Creative Commons Attribution-NonCommercial-NoDerivatives 4.0 License. 
dating this point, I will introduce examples of such processes (3) and shed light on the significance of these processes for society's handling of social problems (4). I will close by briefly mentioning some desiderata (5).

\section{The Controversy between "Objectivistic" Tradition and Constructivism}

Beginning in the 1970s, interactionists criticized the long-dominant structural-functionalist view of "social problems" for its "objectivistic" position on the grounds that it was unable to provide precise criteria to determine when a condition deemed "problematic" qualifies as a "social problem.” For Merton $(1971 ; 1976)$, the existence of a social problem required that there be a "significant discrepancy between social standards and social actuality" (Merton, 1971: 799), and for such a discrepancy (latent social problem) to become a manifest social problem, experts-scientists, that is-had to identify and call out that discrepancy. Yet, aside from the objection that, in complex societies, there were no universally shared values, the critics further objected that discrepancies between the ideal and the real world were ubiquitous and the objectivistic position failed to specify criteria for determining which of those many discrepancies between the ideal and the real could claim significance over those that could not. Moreover, they argued that the objectivists would regularly maintain that, in some circumstances, problematic conditions also served positive social functions. But how can we decide whether a condition constitutes a social problem if it also contributes to the solution of some other potential or "real" problem?

As a symbolic interactionist, Blumer (1971) insisted that no condition comes with an inherent objective quality by its very nature but that its meaning is negotiated and attributed in concrete social interactions. In this view, social problems are not objectively discernable deficiencies but rather results of collective action that are the outcome of the activities of various groups of actors, each with its specific perspective, interests, values, resources, and so on, and it is thus these activities that constitute a condition as a social problem. ${ }^{1}$ Kitsuse and Spector (1973: 415) phrased this accordingly: "Thus, we define social problems as the activities of groups making assertions of grievances and claims with respect to some putative conditions." Authors in this line of thought maintained that that there was no connection between certain social conditions and the changes thereof on the one hand and the processes of problematizing a condition and it being constituted as a social problem on the other, yet in making their argument they obviously employed tautological reasoning (see Albrecht, 1990: 15). This assertion drew the criticism of “ontological gerrymandering” (Woolgar and

1 See Spector and Kitsuse (1973; 1977); Kitsuse and Spector (1973). Good introductions to the constructivist “theory" of social problems are Albrecht (1977; 1990; 2001), Best (2003a; b; 2004; 2006; 2013), and Loseke (2003a; b). For a very different position, see Manis (1974a; b). 
Pawluch, 1985). This was because, to verify social problems, they would have to prove that the conditions deemed "problematic" had not changed, yet nevertheless now constituted a social problem on account of "claimsmaking activities"; in essence, this amounts to arguing that the respective condition possesses some sort of objectively identifiable quality that can be separated from such claims, which is in blatant contradiction to their fundamental methodological position.

Contextual constructivists see a way out of this dilemma by considering the context of problematization and the objectivistic reference to that context as a significant part of the analysis, as the constructed nature of objectivistic assumptions and claims can be verified in terms of its appropriateness on the basis of knowledge that is considered evidently valid (Best, 1989: 247). Best (1995: 6f.), however, contends that this maneuver does not blur the difference between objectivistic and constructivist positions, which is a viewpoint that I would not necessarily support.

Even though German-language scholarship has provided some good studies that have attempted to elaborate the different versions of a constructivist sociology of social problems and their relationship to objectivistic approaches ${ }^{2}$ as well as show their limitations and methodological problems, ${ }^{3}$ there is still a need for additional clarification. Despite all warnings of a too restrictive narrowing of the sociology of social problems (Haferkamp, 1987; Albrecht, 2001), the constructivist position has largely prevailed in the German-speaking world. Schetsche (2000; 2001; 2008) in particular has systematically fleshed out this approach in textbook fashion. Regrettably, the controversies among German-language scholarship since the turn of the century have not yielded any systematic advancement and addition of further theoretical perspectives. The only comprehensive study from the pen of a German-speaking author that addresses the key issues and controversies in sufficient detail and makes inspiring suggestions for further theoretical and empirical research is a text by Groenemeyer (2012). Groenemeyer makes perfectly clear that neither an objectivistic nor a radical-constructivist position alone can provide satisfactory solutions. The literature has mostly concentrated on analyzing the processes of the constitution of social problems. It is to these studies that we will now turn.

\section{Selected Analyses of the Constitution of Social Problems}

Studies committed to a constructivist position are frequently closely associated with theories of social movements, since such movements play a key role in establishing a

2 Particular mention needs to be made of the works of Schmidt (1999; 2000) and Hasse and Schmidt (2010), who have presented a lucid elaboration of the theoretical and methodological peculiarities of different versions of constructivism.

3 See, e.g., Albrecht (1990; 2001), Peters (2001), and Groenemeyer (2001; 2012). 
condition as a "social problem" and in the various phases involved in the attempt to solve the problem. As the sociology of social movements will be discussed in another contribution to this volume (Kern, SOCIAL MOVEMENTS, this volume), I will limit myself to a few thoughts on what the theory of resource mobilization has to say about the successful establishment of a social problem. In this view, the choice of diagnostic frame is a crucial determinant of problem construction, and prognostic and motivational frames most certainly play a major role in the recruitment and motivation of actors, without whom successful problematization can hardly be achieved. ${ }^{4}$ Unfortunately, empirical analyses that explicitly draw on theories of social movements to explain the constitution or transformation of established constructs of problems are few and far between in the German-speaking academic world, although Karstedt (1999), in an excellent overview, has made a strong case for the fruitfulness of such a perspective. $^{5}$

The number of German-language publications that analyze the constitution of social problems is rather low compared to the number of US publications. For reasons of space, I will limit the following review to a small selection of issues that have been problematized or, in some significant way, re-problematized in the recent past. The latest as well as currently ongoing processes of problematization and "established" social problems must unfortunately be omitted from consideration. ${ }^{6}$

A critical aspect in the examination of such discourses that potentially lead to the constitution of a social problem is that it is ultimately not possible to justify a compelling selection criterion as to which disciplines, organizations, or even groups of people participating in such a discourse need to be included in this kind of analysis. For the majority of the problems mentioned below, it is obvious that disciplines such as economics, educational science, law, psychology, and above all medicine are at the heart of early steps of problematization, whereas sociology's role is frequently the analysis of the activities of other disciplines rather than problematization activities of its own. This role has the advantage of being able to adopt a distanced stance that is beneficial to the scientific quality of the endeavor, yet it can also make sociology vulnerable to accusations of irrelevance. In adopting this distanced stance, sociology additionally runs the risk of implicitly betraying its own diagnostic abilities. One of the consequences of the involvement of so many disciplines in problematizing an issue is

4 See Benford and Snow (2000) and Snow (2003). See Jasper (2011) on the relevance of emotions for social movements and Amenta and Poletta (2019) on the cultural impact of social movements as preconditions for new mobilization processes.

5 The analysis of discourses among social movements that have been involved in the debates around abortion in the USA and Germany (e.g., by Ferree et al. [2002]) unfortunately did not inspire more than a few similar comparative studies in German-speaking countries. Here mention must be made of Sylvia Wieseler's studies (2004; 2008), informed by social-movement theory, on how society deals with breast cancer. Her internationally comparative perspective and use of the concept of framing has yielded detailed, in-depth analyses.

6 On numerous established social problems, see the contributions in Albrecht and Groenemeyer (2012). 
the huge volume of literature and the large number of documents that must be considered as being part of the discourse. Another aspect that we must bear in mind is that is typically not scholars who initiate a process of problematization but rather those affected as well as "moral entrepreneurs" and media representatives, whose utterances are difficult to collect to any comprehensive degree no matter what kind of empirical research methodology is used because they can show up in an endless variety of texts and sources.

The issue of abortion is one of many examples that illustrates that the constitution of a problem cannot be properly understood as a static phenomenon but must be viewed dynamically. The decriminalization of abortion under certain conditions in many societies has been met with considerable morally and/or religiously motivated resistance (see, e.g., Ferree et al., 2002; Rucht, 1991; Spieker, 2000) and has triggered social movements pro and contra liberalization. Liberalization has sparked new problematization that has crystallized around the so-called post-abortion syndrome (see Lee, 2001), which the opponents of abortion claim to be a real and widespread phenomenon, whereas "neutral" experts doubt this. Yet the latter could not prevent the issue from becoming virulent in political discourse in the USA. ${ }^{7}$ Advocates of legal liberalization see a first step toward a "re-problematization" of abortion in Germany (a) in the continued, if not even intensified, criminalization of "abortion advertising" by physicians who perform them and (b) in the Federal Ministry of Health intending to provide funding for research on the post-abortion syndrome in Germany.

Another example of the great significance that medicine and its specific perspective has in constituting certain conditions as social problems is what has been labeled the deficiency disease of menopause. It is one of many examples of a "medicalization of social problems" (see Conrad, 2007). Medicalization can have significant, yet ambivalent, consequences for dealing with such problems. In the case of "alcohol dependency," medicalization has the effect of mitigating moral condemnation, whereas defining menopause as a medical problem might well serve the expansion of professional domains by "pathologizing" a "natural" condition and thus creating new "business opportunities” (see Kolip, 2000).

The major role of experts in processes of problem constitution is likewise illustrated in the "career" of what has been labeled attention deficit hyperactivity disorder (ADHD), the diagnosis and treatment of which is still subject to controversy among experts $^{8}$ while public attention has waned despite parents and teachers continuing to perceive problems of this kind in a large number of children. The discourse almost turns belligerent when it comes to ADHD medication therapy. Critics emphasize the existence of substantial long-term side-effects, and some accuse parents who accept such treatment of failing their children. Among the public mind and in parts of the

7 See Major et al. (2009), Robinson et al. (2009), and Dadlez and Andrews (2009) for the USA, and Rohde and Woopen (2007) for Germany.

8 On the career of "hyperkinetic disorder," see Conrad and Potter (2000), who critically discuss the medicalization of the phenomenon. 
"expert" community, we encounter ideas on this issue that other discourse participants refute as myths. ${ }^{9}$

Another issue that has drawn exorbitant public attention in recent decades has been burnout syndrome. In the process of its constitution as a social problem, a question that played a major role was to what extent the dominant (medical) conceptualization of the phenomenon and its ultimately structural causes (excessive demands in the workplace and competitive pressure toward self-optimization) were being individualized and medicalized. ${ }^{10}$ This case clearly illustrates the great significance to society of the outcome of this "struggle in the public arena" over how the issue is conceptualized.

Schmidt (1999; 2012) provided an analysis of how psychiatry constructs "pathological gambling" as a social problem, a construct that often fails to distinguish between addictive and non-addictive or legal and illegal gambling, which are both important distinctions for public problematization. So far, public interest in the subject has been relatively low, presumably because the majority of the population has personal experience with gambling and underestimates its risks, ${ }^{11}$ but perhaps also because the direct and indirect social costs of other problems of addiction (e.g., alcohol or tobacco consumption) are forty to fifty times higher. ${ }^{12}$ It seems likely that the potential explosiveness of the problem will soon be discovered since gambling via the Internet can be expected to render "pathological gambling" increasingly less controllable.

Originating in a joke made by a psychiatrist, so-called Internet addiction drew huge international attention (see the overview in Dalal and Basu, 2016) and soon triggered a wave of concern in German-speaking countries. ${ }^{13}$ The reason for this concern was that this phenomenon is seen to have alarming consequences seemingly across all age groups but particularly so for children and youths, as it is a space for engaging in violent computer games, gambling, consumption of pornography, and harassment outside the reach of the usual mechanisms of social control. Especially problematic are computer games since many parents seem to be helpless in the face of their children spending nearly their entire leisure time playing these games, leaving little to no time for homework or socializing with peers. Apart from the consumption of

9 See Brown (2018).

10 See Kaschka, Korczak, and Broich (2011), Neckel and Wagner (2013a; b), Maslach et al. (2001), Kury (2013), Heinemann and Heinemann (2013; 2016), Vogelmann (2013), and Pfiffner and Weber (2008).

11 On the prevalence of gambling addiction in Germany, see Bundeszentrale für gesundheitliche Aufklärung (2016); on its risks and associated problems, see Hayer (2012), Petry et al. (2013), and Schmidt (2001).

12 See Becker (2011: 43ff.) on these social costs, Kleibrink and Köster (2017) on the market for gambling in Germany and on new, problematic kinds of gambling, and Gebhardt and Korte (2018) on the complex legal issues involved.

13 Among many others, see Hahn and Jerusalem (2001), Walter and Schetsche (2003), te Wildt (2015), Petersen et al. (2009), Wölfling et al. (2013), and Braun (2014). 
problematic content, the addiction to being permanently online and spending most of one's time on the Internet is another serious problem. In light of this phenomenon's obvious problematic potential for society, it is astonishing that sociology has hitherto devoted rather little attention to its social problematization (for an exception, see Braun, 2014).

Finally, I would like to address two conditions whose constitution as a social problem has faltered or been "stifled" (so far at least). Serious legal and medical concerns have been raised against male circumcision for religious reasons. ${ }^{14}$ Yet a ruling by a Cologne court that criminalized the practice of circumcision kicked up a storm of outrage, which soon resulted in the legalization of male circumcision. Much more successful was-when measured by the yardstick of public opposition and in terms of jurisprudence-the problematization of female circumcision (more precisely, genital mutilation), which obviously serves the purpose of sexual repression of women and involves severe physical and mental distress. ${ }^{15}$ So far, successful problematization of this matter seems to have been limited to Western societies, some of which accept women seeking refuge from the threat of genital mutilation as grounds for asylum. This issue raises the question of what the chances are for the global diffusion of recognizing genital mutilation as a social problem in light of massive differences between societies in terms of religion, culture, and social stratification.

It can further be shown that, with the exception of a few Western societies, attempts to problematize slaughter according to Jewish or Muslim rites have also failed for similar reasons.

It is the nature of the beast that constructivist case studies tend to shift attention from issues that are only marginally or no longer contested as being social problems to phenomena that are either completely new or sporadic, ephemeral, or perhaps not even "real" issues. The criterion of selection is typically (the often very short-term) public interest, especially that of the mass media, which is guided by an issue's news value and not by its sociological or societal "relevance."16 The spectacular displaces the relevant. It is likewise true, however, that many an issue that initially appears to be irrelevant or bizarre soon becomes a focal point of societal debate and controversy, whereas another state of affairs that was once generally seen as much more severe is viewed as being "normal” after some time has passed.

14 On the discussion of male circumcision in Germany, see Klein (2013). See also Mack (2015), Mehta (2000), Kreß (2014a; b), Siggelkow (2015), and Jens (2013), who have addressed the ethical and legal issues that this involves from an oppositional perspective.

15 See Asefaw (2008), Boddy (1998), Boyle et al. (2001), Herrmann (2000), Kölling (2008), Mende (2011), Okroi (2001), and Peller (2002).

16 Examples are studies on razor blades in Halloween goodies (Best and Horiuchi, 1985) or satanism (Jenkins and Maier-Katin, 1992; Schmied-Knittel, 2008). 


\section{Society's Dealing with Social Problems at the Micro-Social Level: Doing Social Problems}

There are good reasons not to neglect dealing with "established" social problems. For one, no government can afford to ignore social problems in the long run. For another, we must ask how institutions deal with social problems as part of their daily business, how they "shape" them for organizational processing. Let us begin with the second topic; the first will be addressed in section 4 under desiderata.

The German-language literature offers interesting contributions on what in the USA has been called "doing social problems."17 Groenemeyer (2010a) analyzed the relationships between actors' work on conceptualizing problems and the activities of the agencies that are involved in dealing with or providing solutions to problematic conditions. This "social-problem work" depends on factors such as the structures of institutions, the professional self-conception of the actors operating within those structures, the expectations of the addressees of intervention or prevention policies, and the situational circumstances in which the interactions with clients, customers, or patients take place ${ }^{18}$ Case studies ${ }^{19}$ have shown how work to address the problem of "disability" can lead to the organizational reification of disability (Wetzel, 2012), how social problems in the field of social pedagogy transform these problems in specific ways, and how changing conceptions of providing help alters the ways social problems are dealt with in social work. Similar is true for work with the homeless, medical rehabilitation, work with right-wing extremists, the policing of street subcultures, crime prevention, and ethnic discrimination in service organizations as a result of a specific understanding of a problem.

For sociologists, less pleasing is that the once successful push for a sociological perspective in dealing with mental illness is being marginalized by biological psychiatry, which is once again gaining the upper hand (see Groenemeyer, 2008; Kilian, 2008; 2012; and Dellwing, 2008).

In light of the problems of inclusion in schools that are being discussed in German-speaking countries, work devoted to the issues of diversity and inclusion deserves attention as well. Work that needs to be mentioned here is that of Groenemeyer (2014a), who analyzed the problematization of disability, Wansing (2014), who explored ambivalences in the concept of disability, Krell (2014), who discussed the concept of diversity, and Waldschmidt (2014), who investigated the power of distinc-

17 See, for instance, Best (2008) and Loseke (2003a; b).

18 On the concept of "social-problem work," see Schmidt (2008), and on its relation to neo-institutionalism's concept of work, Hasse and Schmidt (2010).

19 The case studies referred to in the following are all from the aforementioned collection by Groenemeyer (2010a). 
tion that becomes manifest in affixing the label of disability and likewise causes social inequality. $^{20}$

However, the critical observer faces the question of to what extent these recent studies on doing social problems extend beyond the insights already gained from the burgeoning research in the field of deviant behavior and social control that was inspired in Germany by Fritz Sack, who introduced the labeling approach into German sociology.

Unfortunately, there are only few fruitful studies of doing social problems from an internationally comparative perspective. ${ }^{21}$

\section{Desiderata}

As the constitution of social problems is a result of controversial discourses in different "arenas," we cannot assume that the discourse participants who lose in this struggle will accept the prevailing conception, especially since the ensuing attempts at remedying the problem can spark a new dynamic-and these attempts will in all likelihood be undertaken, even in cases in which the problem, according to Nedelmann (1986 a; b), is unsolvable in principle in contemporary societies (Schimank, SOCIETY, this volume). Given highly institutionalized conflicts, attempts at solving a problem will oftentimes cause new problems and conflicts in other areas. In the face of the obvious cumulation of crisis situations in recent times, governments must, however, attempt to maintain or gain flexibility, be it by redefining goals or by reinterpreting problems. The latter amounts to altering the cultural milieu of social problems. Conceivable are changes in the degree of differentiation of a social problem, for instance, by breaking it down into subaspects that can be assigned different levels of relevance and that can be addressed to different degrees. A second option would be a strategically well-considered selection of or emphasis on certain norms and values that can be claimed as being violated by a problematic condition so as to create a specific "moral milieu" as an environment in which the relevant discourses are to take place. The third option is to modify the intensity of value-ladenness. The situation becomes critical for a politics of mastering problems when an issue offers only few possibilities for differentiation, is raised as an issue in a tightly integrated moral milieu, and when the issue is highly value laden.

Unfortunately, there is little work that has systematically applied these insightful theoretical considerations to the analysis of how society as a whole handles social

20 See also the works of Wacker (2014), Schulz (2014), and Schäfers (2014), all of which discuss specific aspects of disability and inclusion.

21 A laudable exception is the comparative analysis of dealing with problems of substance abuse. See Pearson (2009); Duprez and Groenemeyer (2009) provide a review of the findings. 
problems. ${ }^{22}$ Research would be desirable that examines selected social problems in an internationally comparative perspective to determine whether similar problematic conditions follow significantly different trajectories depending on whether governmental attempts to solve these problems make varying use of the aforementioned options. ${ }^{23}$ We could expect significant insights from research on what Mauss (1975) once called "aborted" social problems, that is, "problems" that have failed-at least so far-to become established as such.

New social problems do not start their "careers" in all societies, or even in all regions of the same country, at the same time. Problematization begins in some regions or societies and, under some circumstances, gradually diffuses to other regions, countries, or cultural regions. In this respect, globalization is of particular significance. In many societies, globalization has not only caused economic transformations and, in their wake, classical social problems (e.g., unemployment as a result of moving jobs from long-established industrial countries to developing countries) but also furthered conditions that can boost the diffusion of social problems. The evolving global cultural economy is substantially changing the preconditions for the global diffusion of social problems (for the complex relations between globalization and social movements as a source of social problems, see Almeida and Chase-Dunn, 2018; Weiß, GLOBALIZATION AND TRANSNATIOALIZATION, this volume).

Research on the diffusion of social problems is still in its nascent stages and even in the Anglo-American parts of the world has largely been limited to examining diffusion between no more than two societies. However, what we do have, if nothing else, are the theoretical ideas of Joel Best, informed by general diffusion research. ${ }^{24}$ Best names four prerequisites for the diffusion of a social problem: (a) that a specific (sic!) condition is given, (b) that this condition is deemed problematic, (c) that it exhibits specific features, and (d) that it requires that certain measures be taken to master the problem (Best, 2001b). It is obvious that the first two conditions are generally only satisfied when the receiving group or society shares social circumstances and cultural patterns (values, standards, etc.) with the "model society" or there is at least some degree of accordance in this regard. Sharing a common language or familiarity with the language of the other certainly plays an important role as well. ${ }^{25}$ The third prerequisite is extremely complex, as actors may frequently agree that a certain condition is "problematic" while they may strongly disagree on which aspects make it so, what

22 An outstanding study that draws explicitly on Nedelmann's theoretical approach in order to examine the complex of Germany's Hartz IV legislation (a highly controversial piece of legislation in the 1990s to restructure the German system of unemployment and welfare benefits) and the ensuing problems of defining unemployment and neediness has been provided by Ratzka (2010).

23 The excellent review by Groenemeyer et al. (2012) illustrates how fruitful systematic stock-taking of the "politics of social problems" could be.

24 Examples of this research can be found in the collection edited by Best (2001a).

25 This is a condition that makes it much more likely, for instance, that there is diffusion from the Anglo-Saxon cultural regions to German-speaking countries than vice versa. 
the causes are, and what consequences are to be expected. The same is true for the fourth prerequisite, the measures to be adopted for solving the problem. In this regard, cultural values, established policy styles, institutionalized structures, interest dispositions, rivalries, and so on all play a substantial role as well.

The fundamental significance of information streams requires no particular mention in light of the tremendous increase in the possibilities of communication, even though many an authoritarian government attempts to keep tight control of these flows of information.

What has hitherto been woefully neglected is research on the extent to which communication in social networks plays a significant role in the constitution of social problems and society's efforts to address them. So far, the focus of attention has been on legacy media, even though it is obvious that much discourse these days takes place in other media-and, moreover, this discourse is difficult to capture by the usual methodological means. (Hepp, MEDIA AND COMMUNICATION, this volume)

It would be desirable that radical constructivism, contextual constructivism, and interactionistically refined objectivistic approaches continue to coexist as rivals in theory building and research. ${ }^{26}$ Limiting the task of sociology (in the vein of radical constructivism) to examining communication from a process-analytical perspective, investigating the rules according to which communication unfolds from a structureanalytical perspective, and reconstructing a historical semantic from an evolutiontheoretical perspective while remaining disinterested in the question whether the theory built on these insights is also actually correct (Luhmann, 1986: 74) would amount to radically abandoning the critical function of sociology. If we bear Kitsuse and Spector's definition of social problems in mind as "activities of groups making assertions of grievances and claims to some putative conditions" (1973: 415) and recall the images of drowning refugees in the Mediterranean, it does not seem sufficient to restrict our scientific analysis to the semantic analysis of the discourses that revolve around this issue while losing sight of the suffering and the causes of this catastrophe, as both that suffering and the causes thereof most certainly have some relation to the semantics of the discourse participants.

\section{References}

Albrecht, G. Vorüberlegungen zu einer "Theorie sozialer Probleme”. In Soziologie und Sozialpolitik

(Sonderheft 19 der Kölner Zeitschrift für Soziologie und Sozialpsychologie); Ferber, C.v.; Kaufmann, F.-X., Eds.; Westdeutscher Verlag: Opladen, 1977; pp 143-185.

Albrecht, G. Theorie sozialer Probleme im Widerstreit zwischen "objektivistischen" und

"rekonstruktionistischen" Ansätzen. Soziale Probleme 1990, 1, 5-20.

26 For a current overview of the sociology of social problems, see the review by Helge Peters in Soziologische Revue (2019). 
Albrecht, G. Konstruktion von Realität und Realität von Konstruktionen. Soziale Probleme 2001, 12, 116-145.

Albrecht, G.; Groenemeyer, A., Eds. Handbuch soziale Probleme, 2nd., rev. ed., 2 vols.; VS: Wiesbaden, 2012.

Almeida, P.; Chase-Dunn, C. Globalization and Social Movements. Annual Review of Sociology 2018, 44, 189-211.

Amenta, E.; Poletta, F. The Cultural Impacts of Social Movements. Annual Review of Sociology 2019, 45, 279-299.

Asefaw, F. Weibliche Genitalbeschneidung. Hintergründe, gesundheitliche Folgen und nachhaltige Prävention; Helmer: Königstein/T., 2008.

Becker, T. Soziale Kosten des Glücksspiels in Deutschland; Forschungsstelle Glücksspiel Universität Hohenheim: Hohenheim, 2011.

Benford, R. D.; Snow, D. A. Framing Processes and Social Movements: An Overview and Assessment. Annual Review of Sociology 2000, 26, 611-639.

Best, J., Ed. Images of Issues. Typifying Contemporary Social Problems; Aldine de Gruyter: New York, 1989.

Best, J., Ed. Images of Issues. Typifying Contemporary Social Problems, 2nd. ed.; Routledge: Abingdon/New York, 1995.

Best, J., Ed. How Claims Spread. Cross-National Diffusion of Social Problems; Aldine de Gruyter: New York, 2001a.

Best, J. Introduction: The Diffusion of Social Problems; In How Claims Spread. Cross-National Diffusion of Social Problems; Best, J., Ed.; Aldine de Gruyter: New York, 2001b; pp 1-18.

Best, J. But Seriously Folks. The Limitations of the Strict Constructionist Interpretation of Social Problems. In Challenges and Choices. Constructionist Perspectives on Social Problems; Holstein, J. A.; Miller, G., Eds.; Routledge: Abingdon/New York, 2003a; pp 51-69.

Best, J. Social Problems. In Handbook of Symbolic Interactionism; Reynolds, L. T.; Herman-Kinney, N. J., Eds.; Alta Mira Press: Walnut Creek, CA, 2003b; pp 129-147.

Best, J. Theoretical Issues in the Study of Social Problems and Deviance. In Handbook of Social Problems. A Comparative International Perspective; Ritzer, G., Ed.; Sage: Thousand Oaks, 2004; pp 14-29.

Best, J. Amerikanische Soziologie und die Analyse sozialer Probleme. Soziale Probleme 2006, 17, 20-33.

Best, J. Historical Development and Defining Issues of Constructionist Inquiry. In Handbook of Constructionist Research; Holstein, J. A.; Gubrium, J. F., Eds.; The Guilford Press: New York, 2008; pp 41-64.

Best, J. Social Problems. 2nd. ed.; W.W. Norton \& Co.: New York/London, 2013.

Best, J.; Horiuchi, G. T. The Razor Blade in the Apple: The Social Constitution of Urban Legends. Social Problems 1985, 32, 488-499.

Blumer, H. Social Problems as Collective Behavior. Social Problems 1971, 18, 298-306.

Boddy, J. Violence Embodied? Circumcision, Gender Politics, and Cultural Aesthetics. In Rethinking Violence Against Women; Dobash, R. E.; Dobash, R. P., Eds.; Sage: Thousand Oaks, 1998; pp 77-110.

Boyle, E. H.; Songora, F.; Foss, G. International Discourse and Local Politics: Anti-Female-Genital-Cutting Laws in Egypt, Tanzania, and the United States. Social Problems 2001, 48, 524-544.

Braun, U. Exzessive Internetnutzung Jugendlicher im familialen Kontext. Analyen zu Sozialschicht, Familienklima und elterlichem Erwerbsstatus; Springer VS: Wiesbaden, 2014.

Brown, T. ADHS bei Kindern und Erwachsenen - eine neue Sichtweise; Hogrefe: Göttingen, 2018. 
Bundeszentrale für gesundheitliche Aufklärung (BZgA) Glücksspielverhalten und Glücksspielsucht in Deutschland. Ergebnisse des Surveys 2015 und Trends; Bundeszentrale für gesundheitliche Aufklärung: Cologne, 2016.

Conrad, P. The Medicalization of Society. On the Transformation of Human Conditions into Treatable Disorders; Johns Hopkins University Press: Baltimore, Ma., 2007.

Conrad, P.; Potter, D. From Hyperactive Children to ADHD Adults: Observation on the Expansion on Medical Categories. Social Problems 2000, 47, 559-582.

Dadlez, E. M.; Andrews, W. L. Post-Abortion Syndrome: Creating an Affliction. Bioethics 2009, 24, 445-452.

Dalal, P. K.; Basu, D. Twenty Years of Internet Addiction ...Quo Vadis? Indian Journal of Psychiatry 2016, 58, 6-11.

Dellwing, M. “Geisteskrankheit “ als hartnäckige Aushandlungsniederlage. Die Unausweichlichkeit der Durchsetzung von Definitionen sozialer Realität. Soziale Probleme 2008, 19, 150-171.

Duprez, D.; Groenemeyer, A. Drogenkonsum, Drogenprobleme und Drogenpolitik in Europa. Geschichte und aktuelle Entwicklungen im internationalen Vergleich. Soziale Probleme 2009, $20,5-36$.

Ferree, M. M.; Gamson, W. A.; Rucht, D. Shaping Abortion Discourse. Democracy and the Public Sphere in Germany and the United States; Cambridge University Press: Cambridge, 2002.

Gebhardt, I.; Korte, S. Glücksspiel in Deutschland. Ökonomie, Recht, Sucht. 2nd. ed.; De Gruyter: Berlin, 2018.

Groenemeyer, A. Soziologische Konstruktionen sozialer Probleme und gesellschaftliche Herausforderungen - Eine Einführung. Soziale Probleme 2001, 12, 5-27.

Groenemeyer, A. Eine schwierige Beziehung - Psychische Störungen als Thema soziologischer Analysen. Soziale Probleme 2008, 19, 113-135.

Groenemeyer, A., Ed. Doing Social Problems. Mikroanalysen der Konstruktion sozialer Probleme in institutionellen Kontexten; VS: Wiesbaden, 2010a.

Groenemeyer, A. Doing Social Problems - Doing Social Control. Mikroanalysen der Konstruktion sozialer Probleme in institutionellen Kontexten - Ein Forschungsprogramm; In Doing Social Problems. Mikroanalysen der Konstruktion sozialer Probleme in institutionellen Kontexten; Groenemeyer, A., Ed.; VS: Wiesbaden, 2010b; pp 13-56.

Groenemeyer, A. Soziologie sozialer Probleme - Fragestellungen, Konzepte und theoretische Perspektiven. In Handbuch soziale Probleme, 2nd., rev. ed., 2 vols; Albrecht, G.; Groenemeyer, A., Eds.; Springer VS: Wiesbaden, 2012; pp 17-116.

Groenemeyer, A. Diversität und Inklusion bei Beeinträchtigung und Behinderung. Soziale Probleme 2014a, 25, 147-149.

Groenemeyer, A. Soziale Praxis - Institutionen - Diskurse - Erfahrung. Soziale Probleme 2014b, 25, 150-172.

Groenemeyer, A.; Wieseler, S., Eds. Soziologie sozialer Probleme und sozialer Kontrolle Realitäten, Repräsentationen und Politiken. Festschrift für Günter Albrecht; VS: Wiesbaden, 2008 .

Groenemeyer, A.; Wieseler, S. Institutionen der Normativität. In Soziologie sozialer Probleme und sozialer Kontrolle - Realitäten, Repräsentationen und Politiken. Festschrift für Günter Albrecht; VS: Wiesbaden, 2008b; pp 70-97.

Groenemeyer, A.; Hohage, C.; Ratzka, M. Die Politik sozialer Probleme. In Handbuch soziale Probleme, 2nd., rev. ed., 2 vols; Albrecht, G.; Groenemeyer, A., Eds.; VS: Wiesbaden, 2012; pp 117-191.

Haferkamp, H. Theorie sozialer Probleme. Kritik der neueren amerikanischen Problemsoziologie. Kölner Zeitschrift für Soziologie und Sozialpsychologie 1987, 39, 121-131.

Hahn, A.; Jerusalem, M. Internetsucht. Jugendliche gefangen im Netz. In Risikoverhaltensweisen Jugendlicher; Raithel, J., Ed.; Leske + Budrich: Opladen, 2001; pp 279-293. 
Hasse, R.; Schmidt, L. Der Arbeitsbegriff in der Soziologie sozialer Probleme und im Neo-Institutionalismus. Konzeptualisierung und Anwendung im Forschungsfeld Bildungsungleichheit. In Doing Social Problems. Mikroanalysen der Konstruktion sozialer Probleme in institutionellen Kontexten; Groenemeyer, A., Ed.; VS: Wiesbaden, 2010; pp 57-78.

Hayer, T. Jugendliche und glücksspielbezogene Probleme. Risikobedingungen, Entwicklungsmodelle und Implikationen für präventive Handlungsstrategien; Peter Lang: Frankfurt a.M., 2012.

Heinemann, L. V.; Heinemann, T. Die Etablierung einer Krankheit? Wie Burnout in den modernen Lebenswissenschaften untersucht wird. In Leistung und Erschöpfung; Neckel, S.; Wagner, G., Eds.; Suhrkamp: Berlin, 2013; pp 129-147.

Heinemann, L. V.; Heinemann,T. Burnout. Zur gesellschaftlichen Konstruktion einer umstrittenen Diagnose. In Un-Wohl-Gefühle. Eine Kulturanalyse gegenwärtiger Befindlichkeiten; Mixa, E.; Pritz, S. M.; Tumeltshammer, M.; Greco, M., Eds.; transcript: Bielefeld, 2016; pp 235-251.

Herrmann, C. Das Recht auf Weiblichkeit. Hoffnung im Kampf gegen die Genitalverstümmelung; Dietz: Bonn, 2000.

Holstein, J. A.; Miller, G., Eds. Challenges and Choices. Constructionist Perspectives on Social Problems; Routledge: Abingdon/New York, 2003.

Jasper, J. M. Emotions and Social Movements: Twenty Years of Theory and Research. Annual Review of Sociology 2011, 37, 285-303.

Jenkins, P.; Maier-Katin, D. Satanism: Myth and Reality in a Contemporary Moral Panic. Crime, Law and Social Change 1992, 17, 53-75.

Jens, T. Der Sündenfall des Rechtsstaats. Eine Streitschrift zum neuen Religionskampf. Aus gegebenem Anlass; Gütersloher Verlagshaus: Gütersloh, 2013.

Karstedt, S. Soziale Probleme und soziale Bewegungen. In Handbuch soziale Probleme; Albrecht, G.; Groenemeyer, A.; Stallberg, F. W., Eds.; Westdeutscher Verlag: Opladen, 1999; pp 73-111.

Kaschka, W. P.; Korczak, D.; Broich, K. Modediagnose Burn-out. Deutsches Ärzteblatt 2011, 108, 781-787.

Kilian, R. Die Bedeutung der Soziologie psychischer Gesundheit und Krankheit im Zeitalter der biologischen Psychiatrie. Soziale Probleme 2008, 19, 136-149.

Kilian, R. Psychische Krankheit als soziales Problem. In Handbuch soziale Probleme, 2nd., rev. ed., 2 vols.; Albrecht, G.; Groenemeyer, A., Eds.; Springer VS: Wiesbaden, 2012, pp 924-957.

Kitsuse, J. I.; Spector, M. Toward a Sociology of Social Problems: Social Conditions, Value-Judgements, and Social Problems. Social Problems 1973, 20, 407-419.

Kleibrink, J.; Köster, N. Der Glücksspielmarkt in Deutschland. Eine volkswirtschaftliche Betrachtung; Handelsblatt Research Institute: Düsseldorf, 2017.

Klein, C. Die mediale Bearbeitung von gesellschaftlichen Problemen aus soziologischer Sicht. Wie wird Beschneidung als soziales Problem in ausgewählten Printmedien thematisiert. Diplomarbeit Fakultät für Soziologie: Bielefeld, 2013.

Kölling, A. Weibliche Genitalverstümmelung im Diskurs: Exemplarische Analysen zu Erscheinungsformen, Begründungsmustern und Bekämpfungsstrategien; LIT: Berlin, 2008.

Kolip, P. Weiblichkeit ist keine Krankheit. Die Medikalisierung körperlicher Umbruchphasen im Leben von Frauen; Juventa: Munich, 2000.

Krell, G. "Wahrheitsspiele": Diversity versus oder inklusive Intersektionalität? Soziale Probleme 2014, 25, 194-208.

Kreß, H. Religiöse Vorgaben und individuelle Grundrechte im Konflikt: Die Frage der rituellen Beschneidung. Ethica 2014a, 22, 195-218.

Kreß, H. Persönlichkeitsrecht und Selbstbestimmungsrechte von Kindern. Im Anschluss an die Beschneidungsdebatte ethisch, religions- und bildungspolitisch neu zu diskutieren. Zeitschrift für Religionspädagogik 2014b, 13, 60-75. 
Kury, P. Von der Neurasthenie zum Burnout - eine kurze Geschichte von Belastung und Anpassung. In Leistung und Erschöpfung; Neckel, S.; Wagner, G., Eds.; Suhrkamp: Berlin, 2013; pp 107-128.

Lee, E. Reinventing Abortion as a Social Problem: "Postabortion Syndrome" in the United States and Britain. In How Claims Spread. Cross-National Diffusion of Social Problems; Best, J., Ed., Aldine de Gruyter: New York, 2001; pp 39-67.

Loseke, D. R. Thinking about Social Problems. An Introduction to Constructionist Perspectives. 2nd. ed.; Routledge: Abingdon/New York, 2003a.

Loseke, D. R. Evaluating Constructionist Perspectives on Social Problems. In Thinking about Social Problems. An Introduction to Constructionist Perspectives. 2nd. ed.; Loseke, D. R., Ed.; Routledge: Abingdon/New York, 2003b; pp 163-182.

Loseke, D. R.; Best, J., Eds.; Social Problems. Constructionist Readings; Routledge: Abingdon/New York, 2003.

Luhmann, N. Ökologische Kommunikation. Kann die moderne Geselllschaft sich auf ökologische Gefährdungen einstelllen?; Westdeutscher Verlag: Opladen, 1986.

Mack, E. Ethische Legitimität der Beschneidung? Zeitschrift für medizinische Ethik 2015, 61, 99-108.

Major, B.; Appelbaum, M.; Beckman, L.; Dutton, M. A.; Russo, N. F.; West, C. Abortion and Mental Health: Evaluating the Evidence. American Psychologist 2009, 64, 863-890.

Manis, J. G. The Concept of Social Problems: Vox Populi and Sociological Analysis. Social Problems 1974a, 21, 305-315.

Manis, J. G. Assessing the Seriousness of Social Problems. Social Problems 1974b, 22, 1-15.

Maslach, Ch.; Schaufeli, W. B.; Leiter, M. P. Job Burnout. Annual Review of Psychology 2001, 52, 397-422.

Mauss, A. L. Social Problems as Social Movements; J.B. Lippincott: Philadelphia, 1975.

Mehta, D. Circumcision, Body, Masculinity. The Ritual Wound and Collective Violence. In Violence and Subjectivity; Das, V.; Kleinman, A.; Ramphele, M.; Reynolds, P., Eds.; University of California Press: Berkeley, 2000; pp 79-101.

Mende, J. Begründungsmuster weiblicher Genitalverstümmelung. Zur Vermittlung von Kulturrelativismus und Universalismus; transcript: Bielefeld, 2011.

Merton, R. K. Social Problems and Sociological Theory. In Contemporary Social Problems,3d.ed.; Merton, R. K.; Nisbet, R. A., Eds.; Harcourt Brace Jovanovich: New York, 1971; pp 793-845.

Merton, R. K. The Sociology of Social Problems. In Contemporary Social Problems,4th. ed.; Merton, R. K.; Nisbet, R. A., Eds.; Harcourt Brace Jovanovich: New York, 1976; pp 3-43.

Miller, G.; Holstein, J. A., Eds. Constructionist Controversies. Issues in Social Problems Theory; Routledge: Abingdon/New York, 1993.

Neckel, S.; Wagner, G. Einleitung: Leistung und Erschöpfung. In Leistung und Erschöpfung; Neckel, S.; Wagner, G., Eds.; Suhrkamp: Berlin, 2013a; pp 7-25.

Neckel, S.; Wagner, G. Erschöpfung als "schöpferische Zerstörung”. Burnout und gesellschaftlicher Wandel. In Leistung und Erschöpfung; Neckel, S.; Wagner, G., Eds.; Suhrkamp: Berlin, 2013b; pp 203-217.

Nedelmann, B. Das kulturelle Milieu politischer Konflikte. In Kultur und Gesellschaft. Sonderheft 27 der Kölner Zeitschrift für Soziologie; Neidhardt, F.; Lepsius, R. M.; Weiß, J., Eds.; Westdeutscher Verlag: Opladen, 1986a; pp 397-414.

Nedelmann, B. Soziale Probleme und Handlungsflexibilität. Zur Bedeutsamkeit des kulturellen Aspekts sozialer Probleme. In Soziale Arbeit 2000, Bd. 1, Soziale Probleme und Handlungsflexibilität; Oppl, H.; Tomaschek, A., Eds.; Lambertus: Freiburg, 1986b; pp 13-42.

Okroi, E. Weibliche Genitalverstümmelung im Sudan - Female genital mutilation; Akadem.-Wiss.-Verlag: Hamburg, 2001. 
Pearson, G. Entwicklungen von Drogenproblemen und Drogenpolitik in Großbritannien. Soziale Probleme 2009, 20, 37-56.

Peller, A. Chiffrierte Körper - Disziplinierte Körper. Female Genital Cutting. Rituelle Verwendung als Statussymbol; Weissensee-Verlag: Berlin, 2002.

Peters, H. Vermeidbare Objektivismen - Überlegungen zu einer Soziologie der Soziologie sozialer Probleme. Soziale Probleme 2001, 12, 45-55.

Peters, H. Review of A. Javier Trevino (Ed.), The Cambridge Handbook of Social Problems, Volume 1 and 2. Soziologische Revue 2019, 42, 651-658.

Petersen, K. U.; Weymann, N.; Schelb, V.; Thiel, R.; Thomasius, R. Pathologischer Internetgebrauch - Epidemiologie, Diagnostik, Komorbide Störungen und Behandlungsansatz. Fortschritte der Neurologie und Psychiatrie 2009, 77, 263-271.

Petry, J.; Füchtenschnieder-Petry, I.; Vogelsang, M.; Brück, T. Pathologisches Glücksspiel; Deutsche Hauptstelle gegen Suchtgefahren: Hamm, 2013.

Pfiffner, M.; Weber, S. Burnout - Jetzt zahlen alle! Nicht aber bei Anwendung des Verursacherprinzips. In Sozialpolitik nach Verursacherprinzip. Beispiele der Anwendung aus Arbeit, Gesundheit, Sucht, Schule und Wohnen; Wallmann, I., Ed.; Haupt: Bern/Stuttgart/Vienna, 2008; pp 79-99.

Ratzka, M. Eine Untersuchung der "kulturellen Mechanismen" politischer Problembearbeitung von der Entstehung des Arbeitsförderungsgesetzes bis zu Einführung einer Grundsicherung für Arbeitssuchende - oder wie sich der Paradigmenwechsel von der aktiven zur aktivierenden Arbeitsmarktpolitik erklären lässt. Diss. Fakultät für Soziologie, Universität Bielefeld: Bielefeld, 2010.

Ritzer, G., Ed. Handbook of Social Problems. A Comparative International Perspective; Sage: Thousand Oaks, 2004.

Robinson, G. E.; Stotland, N. L.; Russo, N. F.; Lang, J. A.; Occhiogrosso, M. Is There an "Abortion Trauma Syndrome"? Critiquing the Evidence. Harvard Review of Psychiatry 2009, 17, 268-290.

Rohde, A.; Woopen, C. Psychosoziale Beratung im Kontext von Pränataldiagnostik und Evaluation der Modellprojekte in Bonn, Düsseldorf und Essen; Deutscher Ärzteverlag: Cologne, 2007.

Rucht, D. Soziale Bewegungen, Gegenbewegungen und der Staat. Der Abtreibungskonflikt in den USA, Frankreich und der Bundesrepublik. Forschungsjournal Neue Soziale Bewegungen 1991, 4, 31-42.

Schäfers, M. Personenzentrierung als sozialpolitische Programmformel im Zeichen der Inklusion. Zu den Widersprüchlichkeiten einer Neuausrichtung des Hilfesystems für Menschen mit Behinderungen. Soziale Probleme 2014, 25, 317-338.

Scherr, A. Soziale Arbeit und die nicht beliebige Konstruktion sozialer Probleme in der funktional differenzierten Gesellschaft. Soziale Probleme 2001, 12, 73-94.

Schetsche, M. Wissenssoziologie sozialer Probleme. Grundlegung einer relativistischen Problemtheorie; Westdeutscher Verlag: Wiesbaden, 2000.

Schetsche, M. Metatheorie und Analyseprogramm - Zum Doppelstatus der relativistischen Problemtheorie. Soziale Probleme 2001, 12, 28-44.

Schetsche, M. Empirische Analyse sozialer Probleme. Das wissenssoziologische Programm; VS: Wiesbaden, 2008.

Schmidt, L. Psychische Krankheit als soziales Problem. Die Konstruktion des "Pathologischen Glücksspiels"; Leske + Budrich: Opladen, 1999.

Schmidt, L. Varianten des Konstruktivismus in der Soziologie sozialer Probleme. Soziale Welt 2000, 51, 153-172.

Schmidt, L. Wege aus der Glückspielsucht. Zur organisierten Selbsthilfe in den USA. Sucht 2001, 47, 4-11. 
Schmidt, L. Problemarbeit und institutioneller Kontext. In Soziologie sozialer Probleme und sozialer Kontrolle - Realitäten, Repräsentationen und Politiken. Festschrift für Günter Albrecht; Groenemeyer, A.; Wieseler, S., Eds. VS: Wiesbaden, 2008; pp 35-47.

Schmidt, L. Glücksspielsucht. Aufkommen der Problemdefinition und anhaltende Kontroversen. Soziale Probleme 2012, 23, 41-66.

Schmied-Knittel, I. Zweite Beispielanalyse: "Satanisch-ritueller Missbrauch". In Empirische Analyse sozialer Probleme. Das wissenssoziologische Programm; Schetsche, M.; VS: Wiesbaden, 2008; pp 209-232.

Schulz, M. Disability meets Diversity. Dispositivtheoretische Überlegungen zum Verhältnis von Situativität, Intersektionalität, Agency und Blindheit. Soziale Probleme 2014, 25, 286-300.

Siggelkow, G. Die deutsche Beschneidung minderjähriger Jungen - ein Verfassungsbruch: Unheilvoller Triumpf der Religion über Vernunft und Recht; Persimplex: Schwerin, 2015.

Snow, D. A. Social Movements. In Handbook of Symbolic Interactionism; Reynolds, L. T.; Herman-Kinney, N. J., Eds.; Alta Mira Press: Walnut Creek, CA, 2003; pp 811-833.

Spector, M.; Kitsuse, J. I. Social Problems: A Re-Formulation. Social Problems 1973, 21, 145-159.

Spector, M.; Kitsuse, J. I. Constructing Social Problems; Cummings: Menlo Park, Ca., 1977.

Spieker, M. Kirche und Abtreibung in Deutschland. Ursachen und Verlauf eines Konflikts; Ferdinand Schöningh: Paderborn, 2000.

te Wildt, B. Digitale Junkies. Internetabhängigkeit und ihre Folgen für uns und unsere Kinder; Droemer: Munich, 2015.

Vogelmann, F. Eine erfundene Krankheit? Zur Politik der Nichtexistenz. In Leistung und Erschöpfung; Neckel, S.; Wagner, G., Eds.; Suhrkamp: Berlin, 2013; pp 148-161.

Wacker, E. Verwobene Behinderungsprobleme. Diversität und Inklusivität als Spagat und Zwickmühle. Soziale Probleme 2014, 25, 231-267.

Waldschmidt, A. Macht der Differenz. Perspektiven der Disability Studies auf Diversität, Intersektionalität und soziale Ungleichheit. Soziale Probleme 2014, 25, 173-193.

Walter, S.; Schetsche, M. Internetsucht - eine konstruktionistische Fallstudie. Soziale Probleme 2003, 14, 5-40.

Wansing, G. Konstruktion - Anerkennung - Problematisierung. Ambivalenzen der Kategorie Behinderung im Kontext von Inklusion und Diversität. Soziale Probleme 2014, 25, 209-230.

Wetzel, J. Judenfeindliche Stereotypisierungen: Das Beschneidungsurteil im öffentlichen Diskurs. In Beschneidung: Das Zeichen des Bundes in der Kritik. Zur Debatte um das Kölner Urteil; Heil, J.; Kramer, S. J.; Eds.; Metropol: Berlin, 2012; pp 264-295.

Wieseler, S. Framing-Strategien von Gesundheitsbewegungen im politischen Diskurs. Patienteninitiativen und die Reform der Brustkrebsversorgung; Diss. Fakultät für Soziologie: Bielefeld; 2004.

Wieseler, S. Von der Selbsthilfe zur Advocacy-Bewegung. Die Politisierung von Brustkrebs in den Vereinigten Staaten. In Soziologie sozialer Probleme und sozialer Kontrolle - Realitäten, Repräsentationen und Politiken. Festschrift für Günter Albrecht; Groenemeyer, A.; Wieseler, S., Eds. VS: Wiesbaden, 2008; pp 396-424.

Wölfling, K.; Jo, C.; Bengesser, I.; Müller, K. W. Computerspiel- und Internetsucht. Ein kognitiv-behaviorales Behandlungsmanual; Kohlhammer: Stuttgart, 2013.

Woolgar, S.; Pawluch, D. Ontological Gerrymandering. The Anatomy of Social Problems Explanations. Social Problems 1985, 32, 214-227. 
